medRxiv preprint doi: https://doi.org/10.1101/2020.07.23.20160234; this version posted July 25, 2020. The copyright holder for this preprint

(which was not certified by peer review) is the author/funder, who has granted medRxiv a license to display the preprint in perpetuity.

All rights reserved. No reuse allowed without permission.

\title{
Effective Contact Tracing for COVID-19: A Systematic Review
}

Carl-Etienne Juneau, ${ }^{2}$, Anne-Sara Briand, ${ }^{1}$ Tomas Pueyo, ${ }^{2}$ Pablo Collazzo, ${ }^{3}$ Louise Potvin ${ }^{1}$

1. École de santé publique, Université de Montréal, C.P. 6128, succursale Centre-ville, Montréal (Québec) H3C 3J7 (514) 343-6170

2. COVID-19 Work Group, USA.

3. Danube University, Dr.-Karl-Dorrek-Straße 30, 3500 Krems, Austria.

Correspondence to: carl-etienne.juneau@umontreal.ca

\section{ABSTRACT (342 words)}

Background: Contact tracing is commonly recommended to control outbreaks of COVID-19, but its effectiveness is unclear. This systematic review aimed to examine contact tracing effectiveness in the context of COVID-19.

Methods: Following PRISMA guidelines, MEDLINE, Embase, Global Health, and All EBM Reviews were searched using a range of terms related to contact tracing for COVID-19. Articles were included if they reported on the ability of contact tracing to slow or stop the spread of COVID-19 or on characteristics of effective tracing efforts. Two investigators screened all studies.

Results: A total of 32 articles were found. All were observational or modelling studies, so the quality of the evidence was low. Observational studies $(n=14)$ all reported that contact tracing (alone or in combination with other interventions) was associated with better control of COVID-19. Results of modelling studies $(n=18)$ depended on their assumptions. Under assumptions of prompt and thorough tracing with no further transmission, they found that contact tracing could stop an outbreak (e.g. by reducing the reproduction number from 2.2 to 0.57 ) or that it could reduce infections (e.g. by $24 \%-71 \%$ with a mobile tracing app). Under assumptions of slower, less efficient tracing, modelling studies suggested that tracing could slow, but not stop COVID-19.

Conclusions: Observational and modelling studies suggest that contact tracing is associated with better control of COVID-19. Its effectiveness likely depends on a number of factors, including how many and how fast contacts are traced and quarantined, and how effective quarantines are at preventing further transmission. A cautious interpretation suggests that to stop the spread of COVID-19, public health practitioners have 2-3 days from the time a new case develops symptoms to isolate the case and quarantine at least $80 \%$ of its contacts, and that once isolated, cases and contacts should infect zero new cases. Less efficient tracing may slow, but not stop, the spread of COVID-19. Inefficient tracing (with delays of 4-5+ days or less than $60 \%$ of contacts quarantined with no further transmission) may not contribute meaningfully to control of COVID-19. 
medRxiv preprint doi: https://doi.org/10.1101/2020.07.23.20160234; this version posted July 25, 2020. The copyright holder for this preprint (which was not certified by peer review) is the author/funder, who has granted medRxiv a license to display the preprint in perpetuity.

All rights reserved. No reuse allowed without permission.

Funding: LP holds the Canada Research Chair in Community Approaches and Health Inequalities (CRC 950-232541). This funding source had no role in the design, conduct, or reporting of the study.

Competing interests: CEJ has contractual agreements with the Centre intégré universitaire de santé et de services sociaux du Centre-Sud-de-l'île-de-Montréal and is founder of Dr. Muscle and the COVID-19 Science Updates (https://covid1.substack.com/).

Registration: PROSPERO CRD42020198462

Keywords: COVID-19; Systematic review, Contact tracing, Effectiveness, Outbreak control, Epidemic control; 
medRxiv preprint doi: https://doi.org/10.1101/2020.07.23.20160234; this version posted July 25, 2020. The copyright holder for this preprint (which was not certified by peer review) is the author/funder, who has granted medRxiv a license to display the preprint in perpetuity.

All rights reserved. No reuse allowed without permission.

\section{EFFECTIVE CONTACT TRACING FOR COVID-19: A SYSTEMATIC REVIEW}

\section{INTRODUCTION}

On March 11, 2020, the World Health Organization (WHO) characterized COVID-19 as a pandemic. A wide range of interventions have been proposed to control it, including contact tracing (Juneau et al. 2020). WHO guidelines for contact tracing state that "At least $80 \%$ of new cases [should] have their close contacts traced and in quarantine within 72 hours of case confirmation" (WHO, 2020). However, the WHO does not cite peer-reviewed evidence to support these guidelines, and some studies suggest that tracing needs to be more thorough and prompt to be effective (Ferretti et al. 2020; Hellewell et al. 2020). The US and European Centres for Disease Control and Prevention (CDC) also recommend contact tracing, but offer seemingly conflicting advice in the face of widespread transmission, when thousands of new contacts may need to be traced daily. Indeed, the US CDC states that "When a jurisdiction does not have the capacity to investigate a majority of its new COVID-19 cases, [it] should consider suspending or scaling down contact tracing” (US CDC, 2020). On the other hand, the European CDC advises that "Contact tracing should still be considered in areas of more widespread transmission, wherever possible, and in conjunction with physical distancing measures" (ECDC, 2020a). The ECDC also writes that "With increasing numbers of cases [...] public health staff can be supplemented by people who do not have public health backgrounds" and that "With increased numbers of staff, the contact tracing operations require a greater degree of coordination” (ECDC, 2020b). This apparent contradiction and lack of evidence in official recommendations may leave contact tracers wondering which guidelines to follow. Would a large (and costly) contact tracing operation with new staff track enough contacts quickly enough to be effective? Case in point: the UK spent ten billion pounds on its test and trace programme, which may not have been effective (Iacobucci, 2020). How then might contact tracers be maximally effective? In carrying out this systematic review, we aimed to (1) examine contact tracing effectiveness and (2) identify characteristics of effective tracing efforts. Drawing from the evidence, we also aimed to (3) list and present targets for all key steps of the contact tracing process (such as how many and how fast contacts should be 
medRxiv preprint doi: https://doi.org/10.1101/2020.07.23.20160234; this version posted July 25, 2020. The copyright holder for this preprint (which was not certified by peer review) is the author/funder, who has granted medRxiv a license to display the preprint in perpetuity.

All rights reserved. No reuse allowed without permission.

traced), and (4) propose evidence-based guidelines for effective tracing in the context of COVID-19. In the end, we hope that this systematic review will have practical relevance for public health practitioners looking to establish, operate, or oversee effective contact tracing efforts.

\section{METHODS}

We prepared this systematic review in accordance with PRISMA guidelines (Moher et al. 2009) and registered its protocol with PROSPERO (CRD42020198462).

\section{Eligibility criteria}

All studies evaluating the effectiveness of contact tracing efforts in the community (alone or in combination with other interventions) were included. Effectiveness was defined as stopping or slowing the spread of COVID-19 in usual conditions, with outcomes of interest including reproduction numbers and other measures of spread. Randomized trials, observational studies, and modelling studies were included. All methods of contact investigation were considered, including tracing by telephone or via mobile apps. Articles in English, French, Spanish, and Portuguese from all countries were included. Studies were included only if they focused on SARS-CoV-2, as this virus poses unprecedented challenges, notably in terms of spread and transmission (including asymptomatic and presymptomatic transmission). Abstracts, letters, protocols, preprints, and other unreviewed research were excluded, as well as studies limited to hospitals, nursing homes, prisons, and other enclosed spaces where transmission dynamics may not reflect that of the community. Reviews were also excluded, but their reference lists were checked for additional studies.

\section{Search strategy}

MEDLINE (1946 - 2020 July 8), Embase (1974 - 2020 July 10), Global Health (1973 - 2020 Week 26), and All EBM Reviews (2005 - 2020 July 10) were searched using the terms "COVID19” OR “coronavirus disease 2019” OR “SARS-CoV-2” OR “severe acute respiratory syndrome coronavirus 2” OR "2019-NCoV” OR "2019 novel coronavirus” AND “contact tracing” OR 
medRxiv preprint doi: https://doi.org/10.1101/2020.07.23.20160234; this version posted July 25, 2020. The copyright holder for this preprint (which was not certified by peer review) is the author/funder, who has granted medRxiv a license to display the preprint in perpetuity.

All rights reserved. No reuse allowed without permission.

"contact-tracing” OR "tracing contact*" OR "contact follow-up” OR "case detection*” OR "contact investigation*" OR "epidemic investigation*” with no language or date restrictions. To find additional articles, we also reviewed reference lists, used the "related articles" and "cited by" functions in Google Scholar and PubMed, searched our own files, and consulted with colleagues.

\section{Data extraction and synthesis}

Two investigators screened all studies and solved discrepancies by mutual agreement. Characteristics of studies were recorded in a spreadsheet, including: first author, publication date, study design, population, characteristics of contact tracing efforts, and main findings. Meta-analysis was not feasible due to substantial differences in study designs, outcomes, and effect measures. We did not assess risk of bias.

\section{RESULTS}

\section{Result of the search}

A total of 544 papers were found (results in the Supplement). Removing duplicates left 343. We retained 158 based on title, 64 based on abstract, and 27 based on full text. We found one additional study via reference lists and four more via the "cited by" and "similar articles" functions of PubMed and Google Scholar (eFigure in the Supplement). Therefore, this systematic review includes 32 studies (Table 1). All were observational or modelling studies, so the quality of the evidence was low. Results were generally consistent: 14 out of 14 observational studies (100\%) and 16 out of 18 (89\%) modelling studies reported that contact tracing (alone or in combination with other interventions) was associated with better control of COVID-19. However, we cannot rule out a potential publication bias, whereby results of ineffective tracing efforts would not be published.

\section{Observational studies}

Observational studies $(n=14)$ examined the association between contact tracing (in combination with other interventions) and transmission of COVID-19 in China (Bi et al. 
medRxiv preprint doi: https://doi.org/10.1101/2020.07.23.20160234; this version posted July 25, 2020. The copyright holder for this preprint (which was not certified by peer review) is the author/funder, who has granted medRxiv a license to display the preprint in perpetuity.

2020), Hong Kong (Cowling et al. 2020; Lam et al. 2020; Wong et al. 2020), Taiwan (Chen et al. 2020), Singapore (Ng et al. 2020), South Korea (Choi et al. 2020; Choi et al. 2020b), Vietnam (Dinh et al. 2020), France (Bernard Stoecklin et al. 2020), the US (Burke et al. 2020), in African countries (Nachega et al. 2020), and in international comparisons (Wilasang et al. 2020; Davalgi et al. 2020). All reported at least some benefit of contact tracing, although the independent contribution of tracing (vs. other interventions) could not be assessed.

\section{Modelling studies of contact tracing as part of a larger set of interventions}

A number of modelling studies $(n=11)$ examined contact tracing alone or in combination with other interventions to control outbreaks of COVID-19. In 5 studies, the combination of nonpharmaceutical interventions (NPIs) was shown to be effective in China to control the first outbreak (Zu et al. 2020; Maier and Brockmann, 2020; Tang et al. 2020a; Tang et al. 2020b; Lai et al. 2020). These interventions included case isolation, contact tracing, travel restrictions, social distancing, and hand washing, among others. Without any measures, there could have been a 67-fold increase in the number of COVID-19 cases according to Lai et al. (2020). However, in terms of contact tracing, one study showed that the number of contact traced in Wuhan as of January $22^{\text {nd }} 2020$ was insufficient compared to the population size and probably had limited impact on the epidemic control at first (Tang et al. 2020a).

In 5 other studies, the intertwined nature of diagnostic rate (mean time from onset of symptom to case diagnosis) and quarantine rate (proportion of contacts traced and quarantined) was clearly underlined (Goscé et al. 2020; Giordano et al. 2020; Kucharski et al. 2020; Tang et al. 2020c; Wu et al. 2020). For example, one study showed that diagnosis rate would have only minimal impact unless it is combined with improved quarantine efforts (Tang et al. 2020c). Similarly, Wu et al. (2020) showed that the reproduction number could be rapidly reduced under 1 with a combination of rapid testing and effective quarantine. This is in accord with Giordano et al. (2020)'s model of the pandemic in Italy, showing that the peak of the pandemic could have been reached sooner and the number of deaths lessened with increased population-wide testing and contact tracing. Accordingly, Kucharski et al. (2020) 
medRxiv preprint doi: https://doi.org/10.1101/2020.07.23.20160234; this version posted July 25, 2020. The copyright holder for this preprint (which was not certified by peer review) is the author/funder, who has granted medRxiv a license to display the preprint in perpetuity.

All rights reserved. No reuse allowed without permission.

showed that combined case isolation and contact tracing was more effective in diminishing the reproduction number (to 0.94) than mass testing alone (2.5) compared to no measure (2.6). Adding physical distancing and app-based tracing further decreased the reproduction number in this model (0.87). Similarly, a study based on data from London estimated that adding different measures such as weekly universal testing, case isolation, contact tracing and facemask use to lockdown could reduce cumulative deaths by $48 \%$ compared to lockdown alone (Goscé et al. 2020). Hence, the combination of multiple measures may be key in controlling COVID-19.

Concerning contact tracing more specifically, the quarantine rate appeared to be crucial in these articles. Indeed, many showed the possibility of decreasing the number of cumulative cases of COVID-19 with an increased quarantine rate (Tang et al. 2020a; Tang et al. 2020c; Wu et al. 2020; Zu et al. 2020). In one model (Tang et al. 2020c), it was estimated that a rate of only 0.6 (60\% of contacts traced and isolated) could lead to a Rc below 1 and that the rate could be even less with some degree of social distancing maintained. Yet, this finding was not generalizable to all the pandemic phases, with unrealistic values of quarantine rate needed to avoid a rebound in the de-escalation phase where schools were reopened. In another study, based on China's data, increasing the quarantine rate by 10 times led to a reduction of the peak number of infected individuals by $87 \%$ (Tang et al. 2020a). However, it was specified that such high values of quarantine would require important public health resources to control an outbreak. Correspondingly, Kucharski et al. (2020) estimated that a high level of tracing was required to ensure a reproduction number below 1. Lastly, a model looking at transmission dynamics in the state of New York and the US also found that only a small decrease in the cumulative cases and deaths would be derived from a high level of contact traced (Ngonghala et al. 2020).

\section{Modelling studies of contact tracing efforts}

A small number of modelling studies $(n=5)$ examined variations in contact tracing efforts and their impact on effectiveness. Broadly, they found that tracing effectiveness depended on how 
medRxiv preprint doi: https://doi.org/10.1101/2020.07.23.20160234; this version posted July 25, 2020. The copyright holder for this preprint (which was not certified by peer review) is the author/funder, who has granted medRxiv a license to display the preprint in perpetuity.

All rights reserved. No reuse allowed without permission.

many individuals in the community are infected; how fast new cases are tested and isolated; how many of their contacts are traced and quarantined; how fast those contacts are quarantined; and how effective quarantines and isolations are at preventing further transmission. Keeling et al. (2020) estimated that under "optimistic assumptions", with each step executed flawlessly, the basic reproduction number (R0) of an epidemic could be reduced from 3 to 0.18 . When the percentage of contacts traced decreased from $100 \%$ to just over $71 \%$, R0 decreased to just below 1, suggesting that $71 \%$ may be the lowest target to aim for. Similarly, Ferretti et al. (2020) modelled an epidemic with an R0 of 2.0 and assumed perfectly successful quarantine of contacts upon tracing, and perfect prevention of transmission from cases upon isolation. Even under these assumptions, a 3-day delay from initiation of symptoms to case isolation and quarantine of contacts made these interventions ineffective at controlling the epidemic. For a 2 -day delay, about $80 \%$ of cases needed to be isolated and $80 \%$ of their contacts traced and quarantined to control the epidemic. For a 1-day delay, about $70 \%$ case isolation and $70 \%$ contact tracing and quarantine was needed. These results suggest that delays have a substantial effect, and that even under optimistic assumptions, they should be lower than 3 days. Similarly, Kretzschmar et al. (2020) found that with a testing delay of 3 days or longer, even the most efficient tracing could not bring the reproduction number below 1 . In that study, in the most optimistic scenario, testing and tracing delays were set to 0 , and $100 \%$ of contacts were traced. Assuming around $40 \%$ of transmissions occurring before symptom onset and no further transmission upon quarantine, one model predicted that tracing could reduce the reproduction number from 1.2 to 0.8 . A testing delay of more than 1 day required the tracing delay to be at most 1 day or at least $80 \%$ of contacts to be traced to keep the reproduction number below 1, illustrating that as delays increase, more contacts need to be traced and quarantined for a programme to be effective. Under more realistic assumptions, Hellewell et al. (2020) modelled a wide range of scenarios, with varying number of initial cases $(5,20,40)$, R0 $(1.5,2.5,3.5)$, delays (3.43 or 8.09 days), and contacts traced $(0 \%, 20 \%, 40 \%, 60 \%, 80 \%$, $100 \%$ ). In all scenarios, isolation was assumed to be $100 \%$ effective at preventing further transmission. The number of initial cases had a large effect on the probability of achieving control. With an R0 of 2.5 and a 3.43-day delay from symptom onset to isolation, with five 
medRxiv preprint doi: https://doi.org/10.1101/2020.07.23.20160234; this version posted July 25, 2020. The copyright holder for this preprint (which was not certified by peer review) is the author/funder, who has granted medRxiv a license to display the preprint in perpetuity.

All rights reserved. No reuse allowed without permission.

initial cases, there was a greater than $50 \%$ chance of achieving control in 3 months, even when only $20 \%$ of contacts were traced. However, with 40 initial cases, tracing $20 \%$ of contacts lead to fewer than $5 \%$ of simulations controlled; $80 \%$ contact tracing was necessary to control just under $80 \%$ of simulations within 3 months, illustrating the need for swift action. Likewise, as in other modelling studies, the delay from symptom onset to isolation had a substantial effect. With an R0 of 2.5, 20 initial cases, and $80 \%$ of contacts traced, the probability of achieving control decreased from $89 \%$ to $31 \%$ when the delay from symptom onset to isolation was increased from 3.43 to 8.09 days. These results suggest that to be effective, contact tracing should start as soon as cases appear in the community, at least $80 \%$ of contacts should be traced, and delays from symptom onset to isolation should not exceed 3.43 days. Even so, the authors concluded that in most plausible scenarios, tracing alone was insufficient to control an outbreak within 3 months. In perhaps the most realistic modelling study, Peak et al. (2020) examined two combinations of parameters. In the first combination, (the "high-feasibility setting"): (1) $90 \%$ of contacts were traced; (2) the delay was 0.5 days; (3) quarantine reduced infectiousness by 75\%; (4) isolation of cases reduced infectiousness by $90 \%$. In this setting, the epidemic was controlled. Indeed, R0 was reduced from 2.2 to a median of 0.49 (with the longer serial interval of 7.5 days) or 0.57 (with the shorter serial interval of 4.8 days). According to the authors, this represented the upper bounds of efficiency expected of contact tracing efforts. In the second combination (the "low-feasibility setting"): (1) 50\% of contacts were traced; (2) the delay was 2 days; (3) quarantine reduced infectiousness by $25 \%$; (4) isolation of cases reduced infectiousness by $50 \%$. In this setting, the epidemic was not controlled in any scenario, even when R0 was as low as 1.5. These results suggest that inefficient contact tracing may not contribute meaningfully to control of COVID-19. Overall, 5 out of 5 studies (100\%) that modelled contact tracing efforts under optimistic assumptions suggested that contact tracing could stop an outbreak of COVID-19. On the other hand, 4 out of 4 studies (100\%) that modelled less optimistic assumptions suggested that contact tracing alone could slow, but not stop an outbreak of COVID-19. 
medRxiv preprint doi: https://doi.org/10.1101/2020.07.23.20160234; this version posted July 25, 2020. The copyright holder for this preprint (which was not certified by peer review) is the author/funder, who has granted medRxiv a license to display the preprint in perpetuity.

All rights reserved. No reuse allowed without permission.

In addition, two modelling studies did not examine details of contact tracing efforts, but instead focused only on the adoption of a mobile phone tracing app (Yasaka et al. 2020; Currie et al. 2020). Yasaka et al. (2020) estimated that app-based contact tracing could reduce the proportion of population infected (about $80 \%$ infected with no tracing, about 55\% with 25\% adoption of the tracing app, about $45 \%$ with $50 \%$ adoption, and about $35 \%$ with $75 \%$ adoption). Likewise, Currie et al. (2020) found that in the baseline scenario representative of the ongoing situation in Australia, COVID-19 case count was reduced by an estimated 24\% with 27\% adoption of the app (actual adoption as of May 20, 2020), 32\% with 40\% adoption, 55\% with $61 \%$ adoption, and $71 \%$ with $80 \%$ adoption). These studies did not model parameters such as delays from symptom onset to isolation and quarantine effectiveness, thus making optimistic assumptions which could explain the high reductions estimated.

\section{DISCUSSION}

This systematic review aimed to examine contact tracing effectiveness and to identify characteristics of effective tracing programmes. We found that 15 out of 15 observational studies (100\%) and 16 out of $18(89 \%)$ modelling studies reported that contact tracing (alone or in combination with other interventions) was associated with better control of COVID-19. This conclusion is supported by a number of preprints and other unpublished work (Aleta et al. 2020; James et al. 2020; Worden et al. 2020; BC Ministry of Health, 2020).

Our results are in line with those of other reviews. A recent Cochrane review of quarantine (alone or in combination with other public health measures) found that modelling studies consistently reported a benefit of quarantine to control COVID-19, and that early implementation of quarantine and combining quarantine with other public health measures were important to ensure effectiveness (Nussbaumer-Streit et al. 2020). Likewise, a narrative review of contact tracing in patients infected with SARS-CoV-2 concluded that this "classic" strategy could be applied, but that it should be accelerated (Bellmunt et al. 2020). 
medRxiv preprint doi: https://doi.org/10.1101/2020.07.23.20160234; this version posted July 25, 2020. The copyright holder for this preprint (which was not certified by peer review) is the author/funder, who has granted medRxiv a license to display the preprint in perpetuity.

All rights reserved. No reuse allowed without permission.

\section{Evidence-based guidelines for effective tracing in the context of COVID-19}

Drawing from the evidence, this systematic review also aimed to list and present targets for all relevant dimensions of contact tracing, and to propose evidence-based guidelines. To do so, we can break down the steps of the contact tracing process as follows: (1) a new case develops symptoms; (2) the case is tested; (3) if positive, the case is isolated; (4) its contacts are traced; (5) contacts are notified and quarantined; (6) contacts are monitored during quarantine to prevent further transmission. Therefore, contact tracing effectiveness depends on how many individuals in the community are infected; how fast new cases are tested and isolated; how many of their contacts are traced and quarantined; how fast those contacts are quarantined; and how effective isolations and quarantines are at preventing further transmission. We propose guidelines for each of these dimensions in Table 2, along with supporting evidence. This evidence suggests that the current WHO guideline of tracing contacts within 3 days of cases being confirmed may at best slow, but not stop, the spread of COVID-19 (WHO, 2020).

\begin{tabular}{|c|c|c|c|c|}
\hline \multirow[b]{2}{*}{$\begin{array}{l}\text { Dimension of contact } \\
\text { tracing programme }\end{array}$} & \multicolumn{3}{|c|}{ Guidelines } & \multirow[b]{2}{*}{ Evidence base } \\
\hline & $\begin{array}{l}\text { Highly efficient } \\
\text { (can stop the } \\
\text { spread) }\end{array}$ & $\begin{array}{l}\text { Less efficient } \\
\text { (can slow the } \\
\text { spread) }\end{array}$ & $\begin{array}{c}\text { Inefficient } \\
\text { (may not contribute } \\
\text { meaningfully) }\end{array}$ & \\
\hline $\begin{array}{l}\text { How many individuals } \\
\text { in the community are } \\
\text { infected }\end{array}$ & 5 or less & 20 or less & $40+$ & Hellewell et al. 2020 \\
\hline $\begin{array}{l}\text { How fast new cases are } \\
\text { tested and isolated* }\end{array}$ & 1 day or less & 1-2 days & $2+$ days & $\begin{array}{c}\text { Ferretti et al. 2020; } \\
\text { Kretzschmar et al. } 2020\end{array}$ \\
\hline $\begin{array}{c}\text { How many of their } \\
\text { contacts are traced and } \\
\text { quarantined }\end{array}$ & $80 \%$ or more & $71-80 \%$ & Less than $71 \%$ & $\begin{array}{l}\text { Ferretti et al. 2020; } \\
\text { Hellewell et al. 2020; } \\
\text { Keeling et al. 2020; } \\
\text { Kretzschmar et al. 2020 }\end{array}$ \\
\hline $\begin{array}{l}\text { How fast those contacts } \\
\text { are quarantined }\end{array}$ & 1-2 days & 2-3 days & $3+$ days & $\begin{array}{c}\text { Ferretti et al. 2020; } \\
\text { Kretzschmar et al. } 2020\end{array}$ \\
\hline $\begin{array}{l}\text { How effective isolations } \\
\text { and quarantines are at } \\
\text { preventing transmission }\end{array}$ & $100 \%$ & $90-100 \%$ & Less than $75 \%$ & $\begin{array}{l}\text { Ferretti et al. 2020; } \\
\text { Hellewell et al. 2020; } \\
\text { Peak et al. 2020; } \\
\text { Kretzschmar et al. 2020 }\end{array}$ \\
\hline
\end{tabular}


medRxiv preprint doi: https://doi.org/10.1101/2020.07.23.20160234; this version posted July 25, 2020. The copyright holder for this preprint (which was not certified by peer review) is the author/funder, who has granted medRxiv a license to display the preprint in perpetuity.

All rights reserved. No reuse allowed without permission.

Contact tracing begins with a new case. The case develops symptoms, or is suspected (e.g. by being in close contact with another, confirmed case). The case can transmit the virus to others while presymptomatic or asymptomatic (Furukawa et al. 2020), therefore speed at this step is crucial (Keeling et al. 2020; Ferretti et al. 2020; Kretzschmar et al. 2020; Hellewell et al. 2020; Peak et al. 2020). The case should be tested and its results communicated in the shortest possible time. If new cases are not tested, wait to be tested, or wait for test results to be communicated, contact tracing becomes less effective. Thus testing availability and efficiency are important at this step. Testing should be widely available, and the public could be reminded to seek testing at the earliest signs of symptoms. Likewise, systemic delays in communicating test results should be examined and minimised. In the UK, anecdotal evidence suggests that test results were communicated in 2-3 days (Vize, 2020), which is likely to have undermined tracing efforts considerably. In the US, one report of drive-through testing found that when outsourced, tests $(n=476)$ were turned around in a median of 9.21 days (Lindholm et al. 2020). Contact tracing may not be effective with such delays.

Once a case is confirmed, its contacts must be traced. Tracing contacts manually over the telephone has a number of limitations. First, it is likely that not all contacts will be traced. Cases may not disclose, remember, or have contact information for all contacts. For example, a pilot programme in Sheffield, UK, found that two thirds of people contacted through tracing did not fully cooperate (Mahase, 2020). Second, during a peak of COVID-19, thousands of new contacts may need to be traced daily. This poses substantial operational challenges. Large contact tracing efforts with new staff are costly, and may not be able to maintain the level of effectiveness of smaller programmes with experienced staff. For example, UK's test and trace programme cost ten billion pounds and may not have been effective (Iacobucci, 2020). Mobile phone apps and other technologies can circumvent these shortcomings, but raise a number of ethical issues (Bradford et al. 2020; Austin et al. 2020) and pose technological challenges (Ivers and Weitzner, 2020). Moreover, early evidence suggests that contact tracing apps, despite wide encouragement, have limited adoption (Sim and Lim, 2020; Johnson, 2020). Thus, they may only contribute to slowing (but not stopping) spread of COVID-19. 
medRxiv preprint doi: https://doi.org/10.1101/2020.07.23.20160234; this version posted July 25, 2020. The copyright holder for this preprint (which was not certified by peer review) is the author/funder, who has granted medRxiv a license to display the preprint in perpetuity.

All rights reserved. No reuse allowed without permission.

Other key steps of the contact tracing process are isolations and quarantines. Ineffective isolations and quarantines may compromise otherwise flawless tracing efforts. Four of the five modelling studies we have reviewed assumed perfect prevention of transmission at these steps (Keeling et al. 2020; Ferretti et al. 2020; Kretzschmar et al. 2020; Hellewell et al. 2020). This may be difficult to achieve in practice, even if cases and contacts never leave the home. Indeed, Bi et al. (2020) found that household secondary attack rate was 11.2\% (95\% CI 9.1-13.8) in Shenzhen, China, despite contact tracing being in place. Similarly, Park et al. (2020) found that $11.8 \%$ of household contacts had COVID-19 in South Korea. Moreover, Wu and McGoogan (2020) report that in 20 Chinese provinces outside of Hubei, a total of 1183 case clusters were found, of which $64 \%$ were within familial households. Thus it may be more effective to isolate and quarantine outside the home, in hotels or central locations, especially considering many homes ( 1 in 5 in the US) will lack sufficient space to comply with recommendations (Sehgal et al. 2020). If home isolation and quarantine are used nonetheless, information could be provided to new cases and contacts to reduce household transmission. Li et al. (2020) followed 105 index patients and 392 household contacts in Wuhan, China. They found 14 cases had isolated by themselves at home immediately after the onset of symptomswith masks, dining separately, and residing alone. The results showed no infected contacts in the households of these index cases. A final consideration for this step of the process is financial and social support. Contacts may need support for lost wages, daily activities carried out outside the home (e.g. groceries), or questions related to their health (e.g. telephone helpline).

\section{Strengths and limitations}

This study has a number of strengths. To our knowledge, this is the first study to systematically review the effectiveness of contact tracing efforts, and to propose evidence-based guidelines for tracing in the context of COVID-19. While an earlier review of quarantine found only modelling studies for COVID-19 (Nussbaumer-Streit et al. 2020), we found both observational and modelling studies. Therefore, both the overall association of contact tracing with transmission (in observational studies) and the influence of variations in dimensions of 
medRxiv preprint doi: https://doi.org/10.1101/2020.07.23.20160234; this version posted July 25, 2020. The copyright holder for this preprint (which was not certified by peer review) is the author/funder, who has granted medRxiv a license to display the preprint in perpetuity.

All rights reserved. No reuse allowed without permission.

contact tracing efforts on their effectiveness (in modelling studies) could be examined. However, the nature of this body of evidence is also a limitation, as its quality is low, limiting the strength of our conclusions. In addition, we did not assess risk of bias, examine publication bias, or rate the certainty of evidence using GRADE guidelines. We plan to update this paper to address these limitations shortly. Moreover, most observational studies reported results of contact tracing efforts in combination with other interventions, so their individual contribution could only be estimated from modelling studies. Another limitation is the rapidly evolving nature of the pandemic (as of July 2020) and related contact tracing policies and regulations, as well as public perceptions, which are all likely to influence future tracing efforts. A final limitation is we did not discuss implementation-Rajan et al. (2020) describe specific challenges and solutions.

\section{Conclusions}

Contact tracing effectiveness depends on how many individuals in the community are infected; how fast new cases are tested and isolated; how many of their contacts are traced and quarantined; how fast those contacts are quarantined; and how effective quarantines and isolations are at preventing further transmission. A cautious interpretation of the evidence suggests that to stop the spread of COVID-19 with contact tracing, public health practitioners have 2-3 days from the time a new case develops symptoms, to isolate the case and quarantine at least $80 \%$ of its contacts, and that once isolated, cases and contacts should infect zero new cases. The evidence suggests that less efficient tracing may slow, but not stop, the spread of COVID-19, and that inefficient tracing (with delays of 4-5+ days and less than $60 \%$ of contacts quarantined with no further transmission) may not contribute meaningfully to control of COVID-19. Considering the potential human and economic costs of inefficient tracing, we hope that these guidelines can help public health practitioners establish and oversee effective contact tracing efforts. Future research may improve our understanding of their effectiveness by assessing emerging empirical evidence from ongoing efforts, best practices and policy responses, and differences in outcomes across jurisdictions with more or less efficient tracing. 
medRxiv preprint doi: https://doi.org/10.1101/2020.07.23.20160234; this version posted July 25, 2020. The copyright holder for this preprint (which was not certified by peer review) is the author/funder, who has granted medRxiv a license to display the preprint in perpetuity.

\section{REFERENCES}

Aleta A, Martin-Corral D, Pastore y Piontti A et al. Modeling the impact of social distancing, testing, contact tracing and household quarantine on second-wave scenarios of the COVID-19 epidemic. medRxiv 2020.05.06.20092841; doi: https://doi.org/10.1101/2020.05.06.20092841

Austin L, Chiao V, Coleman B, et al. Test, Trace, and Isolate: COVID-19 and the Canadian Constitution (May 22, 2020). Available at SSRN: https://ssrn.com/abstract=3608823 or http://dx.doi.org/10.2139/ssrn.3608823

Bellmunt JM, Caylà JA, Millet JP. Estudio de contactos en infectados por SARS-CoV-2. El papel fundamental de la Atención Primaria y de la Salud Pública [Contact tracing in patients infected with SARS-CoV-2. The fundamental role of Primary Health Care and Public Health] [published online ahead of print, 2020 Jun 5]. Semergen. 2020;S1138-3593(20)30192-1. doi:10.1016/j.semerg.2020.06.001

BC Ministry of Health. COVID-19: Going Forward. 2020 Jun 23. (https://news.gov.bc.ca/files/2020-06-23-Modelling-Technical-Briefing.pdf). Last accessed 2020 July 18.

Bernard Stoecklin S, Rolland P, Silue Y, et al. First cases of coronavirus disease 2019 (COVID19) in France: surveillance, investigations and control measures, January 2020. Euro Surveill. 2020;25(6):2000094. doi:10.2807/1560-7917.ES.2020.25.6.2000094

Bi Q, Wu Y, Mei S, et al. Epidemiology and transmission of COVID-19 in 391 cases and 1286 of their close contacts in Shenzhen, China: a retrospective cohort study [published online ahead of print, 2020 Apr 27] [published correction appears in Lancet Infect Dis. 2020 Jul;20(7):e148]. Lancet Infect Dis. 2020;S1473-3099(20)30287-5. doi:10.1016/S1473$3099(20) 30287-5$ 
medRxiv preprint doi: https://doi.org/10.1101/2020.07.23.20160234; this version posted July 25, 2020. The copyright holder for this preprint (which was not certified by peer review) is the author/funder, who has granted medRxiv a license to display the preprint in perpetuity. All rights reserved. No reuse allowed without permission.

Bradford LR, Aboy M, Liddell K. COVID-19 Contact Tracing Apps: A Stress Test for Privacy, the GDPR and Data Protection Regimes (June 3, 2020). Journal of Law and the Biosciences (2020), University of Cambridge Faculty of Law Research Paper No. 23/2020, Available at SSRN: https://ssrn.com/abstract $=3617578$

Burke RM, Midgley CM, Dratch A, et al. Active Monitoring of Persons Exposed to Patients with Confirmed COVID-19 - United States, January-February 2020. MMWR Morb Mortal Wkly Rep 2020;69:245-246. DOI: http://dx.doi.org/10.15585/mmwr.mm6909el

Campbell M, McKenzie JE, Sowden A, et al. Synthesis without meta-analysis (SWiM) in systematic reviews: reporting guideline. BMJ. 2020;368:16890. Published 2020 Jan 16. doi:10.1136/bmj.16890

Chen CM, Jyan HW, Chien SC, Jen HH, Hsu CY, Lee PC, Lee CF, Yang YT, Chen MY, Chen LS, Chen HH, Chan CC. Containing COVID-19 Among 627,386 Persons in Contact With the Diamond Princess Cruise Ship Passengers Who Disembarked in Taiwan: Big Data Analytics, J Med Internet Res 2020;22(5):e19540, DOI: 10.2196/19540

Choi, H.; Cho, W.; Kim, M.-H.; Hur, J.-Y. Public Health Emergency and Crisis Management: Case Study of SARS-CoV-2 Outbreak. Int. J. Environ. Res. Public Health 2020, 17, 3984.

Choi, JY. COVID-19 in South Korea, Postgraduate Medical Journal 2020; 96 : 399-402.

Cowling, Benjamin J et al. Impact assessment of non-pharmaceutical interventions against coronavirus disease 2019 and influenza in Hong Kong: an observational study. The Lancet Public Health, Volume 5, Issue 5, e279 - e288 
medRxiv preprint doi: https://doi.org/10.1101/2020.07.23.20160234; this version posted July 25, 2020. The copyright holder for this preprint (which was not certified by peer review) is the author/funder, who has granted medRxiv a license to display the preprint in perpetuity.

All rights reserved. No reuse allowed without permission.

Currie DJ, Peng CQ, Lyle DM, Jameson BA, Frommer MS. Stemming the flow: how much can the Australian smartphone app help to control COVID-19? Public Health Res Pract. 2020;30(2):e3022009.

Davalgi S, Malatesh U, Rachana A, et al. Comparison of measures adopted to combat COVID 19 pandemic by different countries in WHO regions. Indian J Comm Health. 2020;32(2).

Dinh L, Dinh P, Nguyen PDM, Nguyen DHN, Hoang T. Vietnam's response to COVID-19: prompt and proactive actions. J Travel Med. 2020;27(3):taaa047. doi:10.1093/jtm/taaa047

ECDC. Contact tracing: public health management of persons, including healthcare workers, having had contact with COVID-19 cases in the European Union - second update. 2020 April 8.

(https://www.ecdc.europa.eu/sites/default/files/documents/Contact-tracing-Public-healthmanagement-persons-including-healthcare-workers-having-had-contact-with-COVID-19cases-in-the-European-Union\%E2\%80\%93second-update_0.pdf). Last accessed 2020 July 13.

ECDC. Contact tracing for COVID-19: current evidence, options for scale-up and an assessment of resources needed. April 2020b.

(https://www.ecdc.europa.eu/sites/default/files/documents/COVID-19-Contract-tracing-scaleup.pdf). Last accessed 2020 July 13.

Ferretti L, Wymant C, Kendall M, et al. Quantifying SARS-CoV-2 transmission suggests epidemic control with digital contact tracing. Science. 2020;368(6491):eabb6936. doi:10.1126/science.abb6936

Furukawa NW, Brooks JT, Sobel J. Evidence Supporting Transmission of Severe Acute Respiratory Syndrome Coronavirus 2 While Presymptomatic or Asymptomatic. Emerg Infect Dis. 2020;26(7):e201595. doi:10.3201/eid2607.201595 
medRxiv preprint doi: https://doi.org/10.1101/2020.07.23.20160234; this version posted July 25, 2020. The copyright holder for this preprint (which was not certified by peer review) is the author/funder, who has granted medRxiv a license to display the preprint in perpetuity.

All rights reserved. No reuse allowed without permission.

Giordano G, Blanchini F, Bruno R, et al. Modelling the COVID-19 epidemic and implementation of population-wide interventions in Italy. Nat Med. 2020;26(6):855-860. doi:10.1038/s41591-020-0883-7

Goscé L, Phillips PA, Spinola P, Gupta DRK, Abubakar PI. Modelling SARS-COV2 Spread in London: Approaches to Lift the Lockdown [published online ahead of print, 2020 May 24]. J Infect. 2020;S0163-4453(20)30315-7. doi:10.1016/j.jinf.2020.05.037

Hellewell J, Abbott S, Gimma A, et al. Feasibility of controlling COVID-19 outbreaks by isolation of cases and contacts [published correction appears in Lancet Glob Health. 2020 Mar 5;:]. Lancet Glob Health. 2020;8(4):e488-e496. doi:10.1016/S2214-109X(20)30074-7

Iacobucci G. Covid-19: Government is criticised for "scandalous" £10bn spent on test and trace programme. BMJ. 2020;370:m2805. Published 2020 Jul 10. doi:10.1136/bmj.m2805

Ivers LC, Weitzner DJ. Can digital contact tracing make up for lost time? The Lancet Public Health. 2020 July 16. doi:https://doi.org/10.1016/S2468-2667(20)30160-2.

James A, Plank MJ, Binny RN, et al. Successful contact tracing systems for COVID-19 rely on effective quarantine and isolation. medRxiv. 2020.06.10.20125013; doi: https://doi.org/10.1101/2020.06.10.20125013

Johnson B. Nearly 40\% of Icelanders are using a covid app-and it hasn't helped much. MIT $\begin{array}{llll}\text { Technology } & \text { Review. } & 2020 & \text { May }\end{array}$ (https://www.technologyreview.com/2020/05/11/1001541/iceland-rakning-c19-covid-contacttracing/). Last accessed 2020 July 22. 
medRxiv preprint doi: https://doi.org/10.1101/2020.07.23.20160234; this version posted July 25, 2020. The copyright holder for this preprint (which was not certified by peer review) is the author/funder, who has granted medRxiv a license to display the preprint in perpetuity.

Juneau CE, Pueyo T, Bell M, Gee G, Collazzo P, Potvin L. Evidence-based, cost-effective interventions to suppress the COVID-19 pandemic: a systematic review. medRxiv. Posted 2020 Jun 15. doi: https://doi.org/10.1101/2020.04.20.20054726

Keeling MJ, Hollingsworth TD, Read JM. Efficacy of contact tracing for the containment of the 2019 novel coronavirus (COVID-19). J Epidemiol Community Health. Published Online First: 23 June 2020. doi: 10.1136/jech-2020-214051

Kretzschmar M, Rozhnova G, Bootsma MJ, et al. Impact of delays on effectiveness of contact tracing strategies for COVID-19: a modelling study. Lancet Pub Health. Published Online First: 16 July 2020. doi:https://doi.org/10.1016/S2468-2667(20)30157-2

Kucharski AJ, Klepac P, Conlan AJK, et al. Effectiveness of isolation, testing, contact tracing, and physical distancing on reducing transmission of SARS-CoV-2 in different settings: a mathematical modelling study [published online ahead of print, 2020 Jun 15]. Lancet Infect Dis. 2020;S1473-3099(20)30457-6. doi:10.1016/S1473-3099(20)30457-6

Lai S, Ruktanonchai NW, Zhou L, et al. Effect of non-pharmaceutical interventions to contain COVID-19 in China [published online ahead of print, 2020 May 4]. Nature. 2020;10.1038/s41586-020-2293-x. doi:10.1038/s41586-020-2293-x

Lam HY, Lam TS, Wong CH, et al. The epidemiology of COVID-19 cases and the successful containment strategy in Hong Kong-January to May 2020 [published online ahead of print, 2020 Jun 21]. Int J Infect Dis. 2020;98:51-58. doi:10.1016/j.ijid.2020.06.057

Li W, Zhang B, Lu J, et al. The characteristics of household transmission of COVID-19 [published online ahead of print, 2020 Apr 17]. Clin Infect Dis. 2020;ciaa450. doi:10.1093/cid/ciaa450 
medRxiv preprint doi: https://doi.org/10.1101/2020.07.23.20160234; this version posted July 25, 2020. The copyright holder for this preprint (which was not certified by peer review) is the author/funder, who has granted medRxiv a license to display the preprint in perpetuity.

All rights reserved. No reuse allowed without permission.

Lindholm DA, Kiley JL, Jansen NK et al. Outcomes of COVID-19 Drive-through Screening at an Academic Military Medical Center. Open Forum Infectious Diseases. 2020 Jul 17. doi: https://doi.org/10.1093/ofid/ofaa306

Mahase E. Covid-19: Two thirds of people contacted through tracing did not fully cooperate, pilot scheme finds. BMJ. 2020;369:m2169. Published 2020 May 29. doi:10.1136/bmj.m2169

Maier BF, Brockmann D. Effective containment explains subexponential growth in recent confirmed COVID-19 cases in China. Science. 2020;368(6492):742-746. doi:10.1126/science.abb4557

Moher D, Liberati A, Tetzlaff J, Altman DG; PRISMA Group. Preferred reporting items for systematic reviews and meta-analyses: the PRISMA statement. BMJ. 2009 Jul 21;339:b2535. doi: 10.1136/bmj.b2535.

Nachega JB, Grimwood A, Mahomed H, et al. From Easing Lockdowns to Scaling-Up Community-Based COVID-19 Screening, Testing, and Contact Tracing in Africa - Shared Approaches, Innovations, and Challenges to Minimize Morbidity and Mortality [published online ahead of print, 2020 May 31]. Clin Infect Dis. 2020;ciaa695. doi:10.1093/cid/ciaa695

Ng Y, Li Z, Chua YX, et al. Evaluation of the Effectiveness of Surveillance and Containment Measures for the First 100 Patients with COVID-19 in Singapore - January 2-February 29, 2020. MMWR Morb Mortal Wkly Rep. 2020;69(11):307-311. Published 2020 Mar 20. doi:10.15585/mmwr.mm691lel

Ngonghala CN, Iboi E, Eikenberry S, et al. Mathematical assessment of the impact of nonpharmaceutical interventions on curtailing the 2019 novel Coronavirus. Math Biosci. 2020;325:108364. doi:10.1016/j.mbs.2020.108364 
medRxiv preprint doi: https://doi.org/10.1101/2020.07.23.20160234; this version posted July 25, 2020. The copyright holder for this preprint (which was not certified by peer review) is the author/funder, who has granted medRxiv a license to display the preprint in perpetuity. All rights reserved. No reuse allowed without permission.

Nussbaumer-Streit B, Mayr V, Dobrescu AI, et al. Quarantine alone or in combination with other public health measures to control COVID-19: a rapid review. Cochrane Database Syst Rev. 2020;4(4):CD013574. Published 2020 Apr 8. doi:10.1002/14651858.CD013574

Park YJ, Choe YJ, Park O, Park SY, Kim YM, Kim J, et al. Contact tracing during coronavirus disease outbreak, South Korea, 2020. Emerg Infect Dis. 2020 Jul 16. https://doi.org/10.3201/eid2610.201315

Peak, CM, Kahn, R, Grad, YH, Childs, LM, Li, R, Lipsitch, M, O’Buckee, C. Individual quarantine versus active monitoring of contacts for the mitigation of COVID-19: a modelling study. The Lancet, May 2020. https://doi.org/10.1016/S1473-3099(20)30361-3.

Rajan S, Cylus JD, Mckee M. What do countries need to do to implement effective 'find, test, trace, isolate and support' systems? J Royal Soc Med. 2020 July 14. doi:

https://doi.org/10.1177/0141076820939395

Sim D, Lim K. Coronavirus: why aren’t Singapore residents using the TraceTogether contacttracing app? South China Morning Post. 2020 May 18. (https://www.scmp.com/weekasia/people/article/3084903/coronavirus-why-arent-singapore-residents-using-tracetogether). Last accessed 2020 July 27.

Sehgal AR, Himmelstein DU, Woolhandler S. Feasibility of Separate Rooms for Home Isolation and Quarantine for COVID-19 in the United States [published online ahead of print, 2020 Jul 21]. Ann Intern Med. 2020;10.7326/M20-4331. doi:10.7326/M20-4331

Tang B, Wang X, Li Q, et al. Estimation of the Transmission Risk of the 2019-nCoV and Its Implication for Public Health Interventions. J Clin Med. 2020a;9(2):462.. doi:10.3390/jcm9020462 
medRxiv preprint doi: https://doi.org/10.1101/2020.07.23.20160234; this version posted July 25, 2020. The copyright holder for this preprint (which was not certified by peer review) is the author/funder, who has granted medRxiv a license to display the preprint in perpetuity.

All rights reserved. No reuse allowed without permission.

Tang B, Bragazzi NL, Li Q, Tang S, Xiao Y, Wu J. An updated estimation of the risk of transmission of the novel coronavirus (2019-nCov). Infect Dis Model. 2020b;5:248-255. doi:10.1016/j.idm.2020.02.001

Tang B, Scarabel F, Bragazzi NL, et al. De-Escalation by Reversing the Escalation with a Stronger Synergistic Package of Contact Tracing, Quarantine, Isolation and Personal Protection: Feasibility of Preventing a COVID-19 Rebound in Ontario, Canada, as a Case Study. Biology (Basel). 2020c;9(5):100. doi:10.3390/biology9050100

US CDC. HEALTH DEPARTMENTS: Interim Guidance on Developing a COVID-19 Case Investigation \& Contact Tracing Plan. 2020 May 26. (https:/www.cdc.gov/coronavirus/2019ncov/downloads/case-investigation-contact-tracing.pdf). Last accessed 2020 July 13.

Vize R. Too slow and fundamentally flawed: why test and trace is a weak and inequitable defence against covid-19. BMJ. 2020;369:m2246. Published 2020 Jun 11. doi:10.1136/bmj.m2246

WHO. Public health criteria to adjust public health and social measures in the context of COVID-19. 2020 May 12.

(https://apps.who.int/iris/bitstream/handle/10665/332073/WHO-2019-nCoV-

Adjusting_PH_measures-Criteria-2020.1-eng.pdf). Last accessed 2020 July 13.

Wilasang C, Sararat C, Jitsuk NC, et al. Reduction in effective reproduction number of COVID-19 is higher in countries employing active case detection with prompt isolation [published online ahead of print, 2020 Jun 8]. J Travel Med. 2020;taaa095. doi:10.1093/jtm/taaa095

Wong SYS, Kwok KO, Chan FKL. What can countries learn from Hong Kong's response to the COVID-19 pandemic?. CMAJ. 2020;192(19):E511-E515. doi:10.1503/cmaj.200563 
medRxiv preprint doi: https://doi.org/10.1101/2020.07.23.20160234; this version posted July 25, 2020. The copyright holder for this preprint (which was not certified by peer review) is the author/funder, who has granted medRxiv a license to display the preprint in perpetuity.

All rights reserved. No reuse allowed without permission.

Worden L, Wannier R, Blumberg S et al. Estimation of effects of contact tracing and mask adoption on COVID-19 transmission in San Francisco: a modeling study. medRxiv 2020.06.09.20125831; doi: https://doi.org/10.1101/2020.06.09.20125831

Wu J, Tang B, Bragazzi NL, Nah K, McCarthy Z. Quantifying the role of social distancing, personal protection and case detection in mitigating COVID-19 outbreak in Ontario, Canada. J Math Ind. 2020;10(1):15. doi:10.1186/s13362-020-00083-3

Wu Z, McGoogan JM. Characteristics of and Important Lessons From the Coronavirus Disease 2019 (COVID-19) Outbreak in China: Summary of a Report of 72314 Cases From the Chinese Center for Disease Control and Prevention. JAMA. 2020;323(13):1239-1242. doi:10.1001/jama.2020.2648

Yasaka TM, Lehrich BM, Sahyouni R. Peer-to-Peer Contact Tracing: Development of a Privacy-Preserving Smartphone App. JMIR Mhealth Uhealth 2020;8(4):e18936 DOI: $10.2196 / 18936$.

Zu J, Li ML, Li ZF, Shen MW, Xiao YN, Ji FP. Transmission patterns of COVID-19 in the mainland of China and the efficacy of different control strategies: a data- and model-driven study. Infect Dis Poverty. 2020;9(1):83. Published 2020 Jul 6. doi:10.1186/s40249-020-00709-z 


\section{SUPPLEMENT-RESULT OF THE SEARCH}

\begin{tabular}{|c|c|c|}
\hline Step & Searches & Results \\
\hline 1 & $\begin{array}{l}\text { COVID-19.mp. [mp=ti, ot, ab, nm, hw, kw, fx, kf, ox, px, rx, ui, an, sy, tx, sh, ct, tn, } \\
\text { dm, mf, dv, dq, bt, id, cc] }\end{array}$ & 56118 \\
\hline 2 & $\begin{array}{l}\text { SARS-CoV-2.mp. [mp=ti, ot, ab, nm, hw, kw, fx, kf, ox, px, rx, ui, an, sy, tx, sh, ct, tn, } \\
\text { dm, mf, dv, dq, bt, id, cc] }\end{array}$ & 17748 \\
\hline 3 & $\begin{array}{l}\text { 2019-NCoV.mp. [mp=ti, ot, ab, nm, hw, kw, fx, kf, ox, px, rx, ui, an, sy, tx, sh, ct, tn, } \\
\text { dm, mf, dv, dq, bt, id, cc] }\end{array}$ & 1953 \\
\hline 4 & $\begin{array}{l}\text { coronavirus disease 2019.mp. [mp=ti, ot, ab, nm, hw, kw, fx, kf, ox, px, rx, ui, an, sy, } \\
\text { tx, sh, ct, tn, dm, mf, dv, dq, bt, id, cc] }\end{array}$ & 29369 \\
\hline 5 & $\begin{array}{l}\text { severe acute respiratory syndrome coronavirus } 2 . \mathrm{mp} \text {. [mp=ti, ot, ab, nm, hw, kw, fx, } \\
\mathrm{kf}, \mathrm{ox}, \mathrm{px}, \mathrm{rx}, \mathrm{ui}, \mathrm{an}, \mathrm{sy}, \mathrm{tx}, \mathrm{sh}, \mathrm{ct}, \mathrm{tn}, \mathrm{dm}, \mathrm{mf}, \mathrm{dv}, \mathrm{dq}, \mathrm{bt}, \mathrm{id}, \mathrm{cc}]\end{array}$ & 18947 \\
\hline 6 & $\begin{array}{l}2019 \text { novel coronavirus.mp. [mp=ti, ot, ab, nm, hw, kw, fx, kf, ox, px, rx, ui, an, sy, tx, } \\
\text { sh, ct, tn, dm, mf, dv, dq, bt, id, cc] }\end{array}$ & 1849 \\
\hline 7 & 1 or 2 or 3 or 4 or 5 or 6 & 61984 \\
\hline 8 & $\begin{array}{l}\text { contact tracing.mp. [mp=ti, ot, ab, nm, hw, kw, fx, kf, ox, px, rx, ui, an, sy, tx, sh, ct, } \\
\text { tn, dm, mf, dv, dq, bt, id, cc] }\end{array}$ & 9591 \\
\hline 9 & $\begin{array}{l}\text { contact-tracing.mp. [mp=ti, ot, ab, nm, hw, kw, fx, kf, ox, px, rx, ui, an, sy, tx, sh, ct, } \\
\text { tn, dm, mf, dv, dq, bt, id, cc] }\end{array}$ & 9591 \\
\hline 10 & 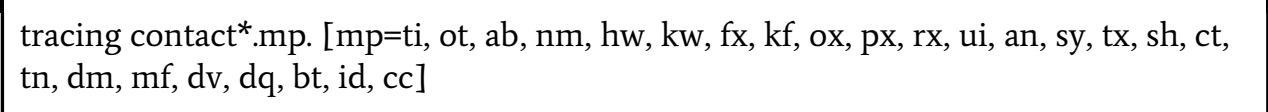 & 79 \\
\hline 11 & $\begin{array}{l}\text { contact follow-up.mp. [mp=ti, ot, ab, nm, hw, kw, fx, kf, ox, px, rx, ui, an, sy, tx, sh, } \\
\text { ct, tn, dm, mf, dv, dq, bt, id, cc] }\end{array}$ & 177 \\
\hline 12 & $\begin{array}{l}\text { case detection*.mp. [mp=ti, ot, ab, nm, hw, kw, fx, kf, ox, px, rx, ui, an, sy, tx, sh, ct, } \\
\text { tn, dm, mf, dv, dq, bt, id, cc ] }\end{array}$ & 8391 \\
\hline 13 & $\begin{array}{l}\text { contact investigation*.mp. [mp=ti, ot, ab, nm, hw, kw, fx, kf, ox, px, rx, ui, an, sy, tx, } \\
\text { sh, ct, tn, dm, mf, dv, dq, bt, id, cc] }\end{array}$ & 2259 \\
\hline 14 & $\begin{array}{l}\text { epidemic investigation*.mp. [mp=ti, ot, ab, nm, hw, kw, fx, kf, ox, px, rx, ui, an, sy, tx, } \\
\text { sh, ct, tn, dm, mf, dv, dq, bt, id, cc] }\end{array}$ & 267 \\
\hline 15 & 8 or 9 or 10 or 11 or 12 or 13 or 14 & 19697 \\
\hline 16 & 7 and 15 & 544 \\
\hline 17 & remove duplicates from 16 & 343 \\
\hline
\end{tabular}


medRxiv preprint doi: https://doi.org/10.1101/2020.07.23.20160234; this version posted July 25, 2020. The copyright holder for this preprint (which was not certified by peer review) is the author/funder, who has granted medRxiv a license to display the preprint in perpetuity. All rights reserved. No reuse allowed without permission.

\section{SUPPLEMENT}

\section{eFigure-PRISMA Flow Diagram}

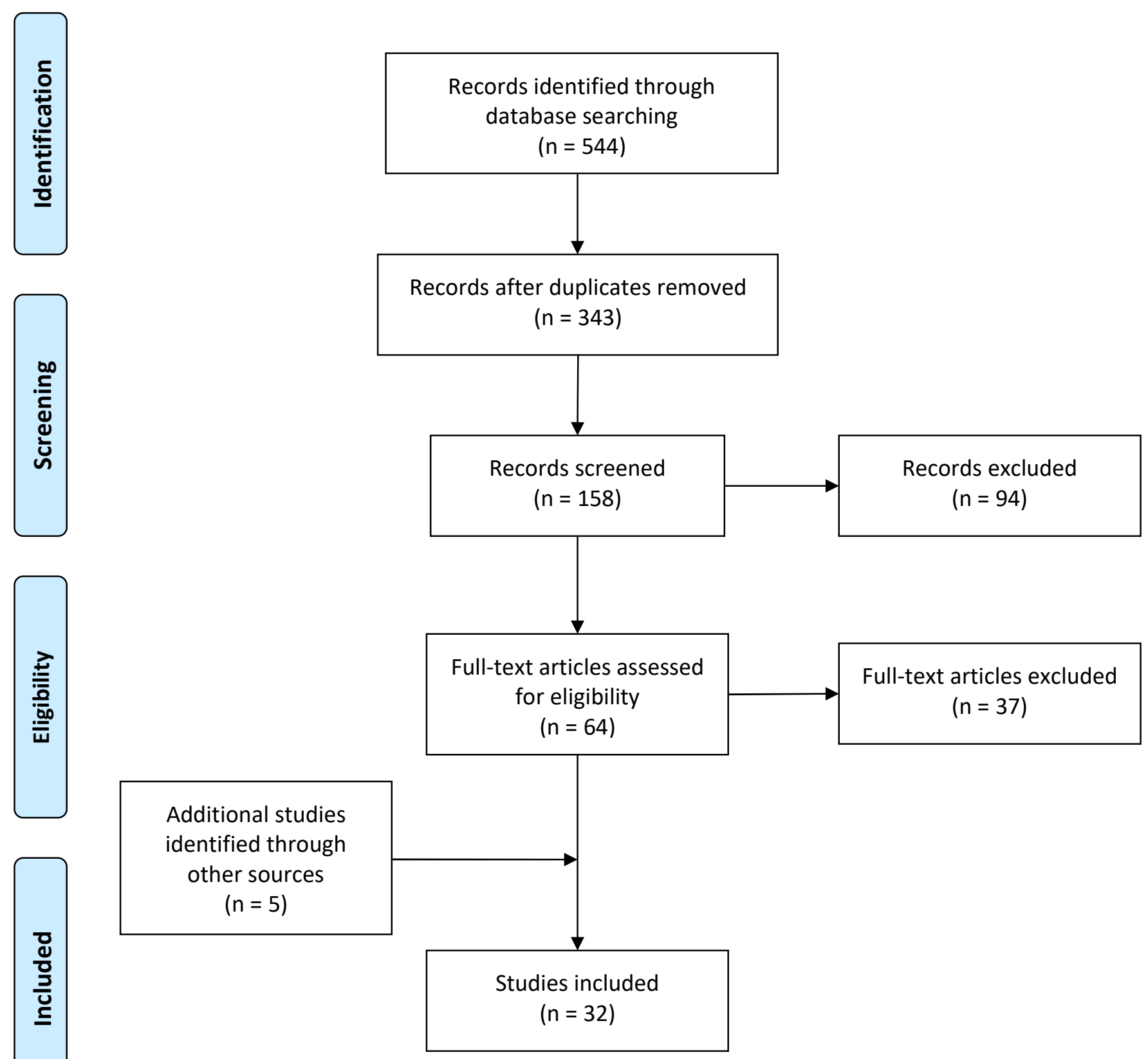

From: Moher D, Liberati A, Tetzlaff J, Altman DG, The PRISMA Group (2009). Preferred Reporting Items for Systematic Reviews and MetaAnalyses: The PRISMA Statement. PLoS Med 6(7): e1000097. doi:10.1371/journal.pmed1000097 